\title{
Effects of Climatic Conditions on Distribution and Fluctuation of Some Pests on The Eggplant Plantations in Summer and Autumn Seasons
}

\author{
Ramadan M. Farrag and Ehsan A. Zakzouk ${ }^{1}$
}

\begin{abstract}
The work aimed to indicate the differences in species and population densities of pests, which were found on the eggplant plantations (cv. Roma) in summer and autumn seasons in Alexandria.

The results showed that presence of the red spider mite (Tetranychus urticae), whitefly (Bemisia tabaci), potato tuber moth (Phthorimae opercellula), semi-looper (Autographa spp.), onion thrips (Thrips tabaci) and the predator aphid-lion (Chrysopa vulgaris) in autumn season. While, T.urticae, B. tabaci and Autographa spp. were found in summer.

T.urticae gave the highest number in the two seasons, especially in autumn. The general averages $(\bar{X})$ of eggs, nymphs and adults were $85, \quad 57.1$ and 38.8 individuals/plant, respectively. The corresponding figures were 47.2, 43.1 and 15.1 in summer.

Few numbers of the other-mentioned pests were counted in comparison with $T$. urticae in the two seasons. Therefore, $T$. urticae constitutes the major pest on eggplant and increases in autumn due to high temperature and PSD (possible sunshine duration).

Therefore, effects of some climatic conditions in the two seasons on presence and numbers of pests were studied. In autumn, the simple correlation analysis indicated that PSD was the most effective on eggs of $T$. urticae. Also, amount of rain showed significantly negative correlations on $T$. urticae stages in autumn season. Concerning summer season, PSD had significantly effect on adults of $T$. urticae. It is evident that some climatic conditions have effects on population dynamics of some pests, and PSD was the most important factor on $T$. urticae.
\end{abstract}

Also, treatments of abamectin and micronized sulfur induced reduction in eggs, nymphs and adults of $T$. urticae after 2, 5 and 7 days of application with the highest effect of abamectin after 7 days. Significant differences were noticed between treatments and days post-treatment.

\section{INTRODUCTION}

The eggplant (Solanum melongena) is among the important vegetable crops in Egypt, therefore the cultivated areas increase annually. The cultivation of this crop require a deep knowledge of many variables such as the suitable soil, irrigaration, fertilization, climate and pests, which affect on yield. Nagai (1991), Ho and Chen (1992), Farrag and Zakzouk (1998) dealt with pests and their control on this crop.

\footnotetext{
${ }^{1}$ Plant Protection Research Institute, Agricultural Research Center, Sabahia, Alexandria

Received Febuary 6, 2014, Accepted March 9, 2014
}

The climatic changes could be effect on population density of pests. Therefore, the first aim of this work is to study the effects of climatic conditions in autumn and summer on species and density of pests on eggplant. The meteorological parameters during periods of inspection in years of 2012 and 2013 were obtained from the Egyptian Meteorological Authority, Egypt. Previous studies dealt with relationship between climatic conditions and population density of pests (ElHalawany et al., 1990; Abdel-Halim, 1994 and Zakzouk and Farrag, 1998).

In regard to chemical control, it has played major role in controlling pests, although it has harmful effect on environment. Consequently, the second aim is to compare the effects of biocide abamectin with inorganic compound sulfur on stages of T. urticae after several days of spraying.

\section{MATERIALS AND METHODS}

I- The test-treatments

-Sulfur (Micronized Soreil/Smark 70\% WP, at the dose of $250 \mathrm{~g} / 100 \mathrm{~L}$. water.).

-Abamectin (Vertimec 1.8\% EC, at the dose of 40 $\mathrm{cm}^{3} / 100 \mathrm{~L}$.).

\section{II- Field experimets}

The trials were achieved at the grower fields at ElMaamoura region, Alexandria. The long black eggplant (cv. Roma) was transplated on 23 Sept., 2012 and on 15 March, 2013 in the autumn and summer seasons, respectively. This variety tolerates the low temperature in open fields during growing periods.

The area was divided into plots $\cong 100 \mathrm{~m}^{2}$ with 3 replicates. Thirty leaves of 10 plants were detached from lower, middle and upper parts of each plant per plot. The leaves were examined in laboratory to identify and count the present species. The work was done at 2 weeks intervals as indicated in Tables (1\&2).

Also, effects of abamectin and sulfur on T.urticae stages were studied. The treatments were sprayed on plant using knaspack sprayer with 3 replicates per treatment and untreated plots as control. The efficacy was compared on eggs, nymphs and adults at 2, 5 and 7 days after treatment. The efficacy was determined by 
calculating the percent reduction $(\% \mathrm{R})$ of these stages by using Henderson-Tilton's formula (Henderson and Tilton, 1955).

The data were analysed and means were separately with LSD test at 0.05 level (Steel and Torrie, 1980). Also, simple correlations between meteorological paratmers and population density of each pest species in the two seasons were estimated.

\section{RESULTS AND DISCUSSIONS}

\section{1- Survey and population density}

\section{1- In autumn season}

Data in Table (1) show the pest species and associated predator, which were found in this period on the eggplant. The pests of $T$. urticae, B. tabaci, $P$. opercellula, T. tabaci, Autographa spp. and the predator of $C$. vulgaris were found and varied in their densities during Oct. till Dec., 2012.

T. urticae was the dominant pest with the highest numbers during Oct., 11 - Nov., 9. The mean number of eggs, nymphs and adults were 237, 87.3 and 58 individuals/plant on Oct., 11 respectively. While, the values were 109, 107.7 and 33.7, resp. on Nov., 9. After that, declining number rates of the above-mentioned stages were noticed. Significant differences were estimated during this period. It seems that $T$. urticae is influenced by climatic conditions in the growing season.

Also, B. tabaci was varied during this period, showing 6.7 - 0.7 eggs/ plant during Oct.,11-Dec.,22. While, the values of pupae were 20.7-5/ plant. The little numbers of $P$. opercellula larvae, Autographa larvae, $T$. tabaci nymphs and $C$. vulgaris adults were counted and presented in Table (1).

\section{2- In summer season}

Data in Table (2) indicated presence of T. urticae and little numbers of Autographa spp. The highest infestation of $T$. urticae were occurred with means of 120.7 - 95.3 eggs/plant on May 12 and 26. The values of nymphs were 39.3-91, while adults reached 26.3 37.3 /plant. Also, larvae of Autographa spp. reached its max. number on May 26 with 8.7 individuals / plant. Negligible no. B. tabaci was noticed, while the natural enemies were not found.

In 1990, El-Halawany et al. mentioned that $T$. urticae appeared in few numbers on old leaves of apple in winter months (Jan. and Feb.), and the mite had two annual peaks of seasonal abundance, one in June and the other in October. Also, they stated that low temperature from Nov. to Feb. reduces fecundity and prolongs duration of development stages leading to reduction in mite populations. It seems that hot and dry weather cause significant mite outbreak.

Generally, it was noticed that numbers of pests were much higher in autumn season than in summer. $T$. urticae was the most pest on eggplant in the two seasons, particularly in autumn. This might be due to high temperature.

\section{2- Simple correlation analysis}

The simple correlations between the pest population and months in the two seasons are shown in Table (3).

\section{1- In autumn season}

The results show PSD (possible sunshine duration) has the highest positive correlation coefficient on eggs of $T$. urticae eggs followed by maximum and minimum temperature. The r-values were $0.993,0.921$ and 0.886 , respectively. Also, min. and max. temp. showed significant positive correlation with nymphs.

On the other hand, amount of rain gave significantly negative correlations with stages of $T$. urticae. Also, \% $\mathrm{RH}$ showed negative correlation on eggs and adults of this pest.

\section{2- In summer season}

Data in Table (3) show PSD had only significantly correlation with Tetranychus adults, giving r-value equal to 0.766 . While, the other meteorological parameters did not have effect on the other pest stages.

Then, PSD is the major factor may limit the population densities of $T$. urticae in autumn and summer seasons.

\section{3- Efficacy of the test-pesticides on $T$. urticae}

Data in Table (4) indicated the variations in potentional activity of the treatments during the days after application. Sulfur gave higher reduction in eggs, nymphs and adults after 2 days in comparison with abamectin. But, the reduction increased with abamectin after 5 and 7 days induced 94.8, 95.3 and 82.0\% reduction in eggs, nymphs and adults after 7 days, resp. While, they were $80.2,83.2$ and 39.5 with sulfur. Then, abamectin gave the best control after 7 days in the range of $82-95 \%$ reduction in the stages.

Generally, significantly differences were noticed among the treatments and days after application.

Similer findings were observed by using lime sulfur on T. urticae (Giraldo et al., 2013). In 2013, Nour ElDeen and Abdallah indicated that abamectin and micronized sulfur were the most effective compounds against $T$. urticae under laboratory conditions. 
Table 2. Pest species and their densities on eggplant during summer season, 2013 


\begin{tabular}{|c|c|c|c|c|c|c|c|}
\hline \multirow{3}{*}{$\begin{array}{c}\text { Date of } \\
\text { inspection }\end{array}$} & \multicolumn{6}{|c|}{ Mean no. individuals / plant (3 leaves) } & \multirow{3}{*}{$\begin{array}{c}\text { General } \\
\text { Averages } \\
(\mathrm{X})\end{array}$} \\
\hline & \multicolumn{2}{|c|}{ B. tabaci } & \multicolumn{3}{|c|}{ T. urticae } & \multirow{2}{*}{$\begin{array}{c}\text { Autographa } \\
\text { Spp. }\end{array}$} & \\
\hline & eggs & pupae & eggs & nymphs & Adults & & \\
\hline April 14, & $0.0 \mathrm{a}$ & $1.7 \mathrm{a}$ & $5.3 \mathrm{c}$ & $31.3 \mathrm{~b}$ & $1.0 \mathrm{e}$ & $0.3 \mathrm{~b}$ & $6.6 \mathrm{C}$ \\
\hline 28 & $0.0 \mathrm{a}$ & $0.0 \mathrm{a}$ & $23.7 \mathrm{c}$ & $6.0 \mathrm{~b}$ & $6.0 \mathrm{de}$ & $0.0 \mathrm{~b}$ & $6.0 \mathrm{C}$ \\
\hline May 12 , & $0.0 \mathrm{a}$ & $0.0 \mathrm{a}$ & $120.7 \mathrm{a}$ & $39.3 \mathrm{ab}$ & $26.3 \mathrm{~b}$ & $0.7 \mathrm{~b}$ & $31.2 \mathrm{~B}$ \\
\hline 26 & $0.0 \mathrm{a}$ & $1.3 \mathrm{a}$ & $95.3 \mathrm{~b}$ & $91.0 \mathrm{a}$ & $37.3 \mathrm{a}$ & $8.7 \mathrm{a}$ & $38.9 \mathrm{~A}$ \\
\hline June 9 , & $0.0 \mathrm{a}$ & $0.0 \mathrm{a}$ & $70.9 \mathrm{~b}$ & $39.0 \mathrm{ab}$ & $18.3 \mathrm{c}$ & $0.0 \mathrm{~b}$ & $21.4 \mathrm{~B}$ \\
\hline 23 & $0.0 \mathrm{a}$ & $0.0 \mathrm{a}$ & $5.3 \mathrm{c}$ & $64.2 \mathrm{ab}$ & $5.2 \mathrm{de}$ & $0.0 \mathrm{~b}$ & $12.5 \mathrm{C}$ \\
\hline July 7 & $0.0 \mathrm{a}$ & $0.0 \mathrm{a}$ & $9.0 \mathrm{c}$ & $31.0 \mathrm{~b}$ & $11.3 \mathrm{~d}$ & $0.0 \mathrm{~b}$ & $8.6 \mathrm{C}$ \\
\hline $\bar{X}$ & $0.0 \mathrm{C}$ & $0.4 \mathrm{C}$ & $47.2 \mathrm{~A}$ & $43.1 \mathrm{~A}$ & $15.1 \mathrm{~B}$ & $1.4 \mathrm{C}$ & 17.9 \\
\hline
\end{tabular}

Means followed by the same letter in each column are not significantly different at 0.05 level by LSD test.

Table 3. Simple correlations between average no. pests on eggplant and some meteorological parameters in autumn season of 2012 and summer of 2013, Alex

\begin{tabular}{|c|c|c|c|c|c|c|}
\hline \multirow[b]{2}{*}{$\frac{\text { Pests \& }}{\text { Predator }}$} & \multirow[b]{2}{*}{ Stages } & \multicolumn{5}{|c|}{ Meteorological parameters } \\
\hline & & $\begin{array}{c}\text { Min. temp. } \\
\left(\mathbf{C}^{0}\right)\end{array}$ & $\begin{array}{c}\text { Max. temp. } \\
\left(\mathbf{C}^{0}\right)\end{array}$ & PSD & \% RH & $\begin{array}{c}\text { Amm. rain } \\
(\mathbf{m m})\end{array}$ \\
\hline \multicolumn{7}{|l|}{ Autumn 2012} \\
\hline \multirow[t]{2}{*}{ B. tabaci } & eggs & 0.082 & 0.261 & 0.305 & -0.175 & 0.020 \\
\hline & pupae & 0.721 & 0.789 & 0.783 & -0.229 & -0.810 \\
\hline \multirow[t]{3}{*}{ T. urticae } & eggs & $0.886^{*}$ & $0.921 * *$ & $0.993 * * *$ & -0.246 & $-0.860 *$ \\
\hline & nymphs & $0.843^{*}$ & $0.853 *$ & 0.776 & 0.004 & $-0.893 *$ \\
\hline & adults & 0.586 & 0.695 & 0.688 & -0.239 & $-0.732 *$ \\
\hline P. operculella & larvae & 0.607 & 0.620 & 0.807 & -0.340 & -0.474 \\
\hline Autographa spp. & larvae & 0.555 & 0.649 & 0.604 & -0.167 & -0.708 \\
\hline T. tabaci & nymphs & 0.578 & 0.422 & 0.176 & 0.565 & -0.524 \\
\hline C. vulgaris & adults & 0.547 & 0.580 & 0.786 & -0.398 & -0.428 \\
\hline $\bar{X}$ & & $0.850 *$ & $0.903 *$ & $0.913 *$ & -0.819 & $-0.892 *$ \\
\hline \multicolumn{7}{|l|}{ Summer 2013} \\
\hline B. tabaci & pupae & -0.616 & -0.442 & -0.659 & -0.039 & \\
\hline \multirow{3}{*}{ T. urticae } & eggs & 0.117 & 0.426 & -0.075 & -0.085 & \\
\hline & nymphs & 0.399 & -0.256 & 0.137 & 0.469 & \\
\hline & adults & 0.506 & 0.463 & $0.766^{*}$ & 0.142 & \\
\hline Autographa spp. & larvae & 0.020 & 0.164 & 0.100 & -0.110 & \\
\hline$\overline{\mathrm{X}}$ & & 0.256 & 0.253 & 0.016 & 0.231 & \\
\hline
\end{tabular}

Table 4. Potentional activity of abamectin and sulfur on $T$. urticae stages after 2,5 and 7 days of spraying

\begin{tabular}{ccccc}
\hline \multirow{2}{*}{ Pesticides } & $\begin{array}{c}\text { Days after } \\
\text { Application }\end{array}$ & Eggs & Percent reduction (\% R) \\
\cline { 2 - 5 } Abamectin & 2 & $10.7 \mathrm{~d}$ & $10.0 \mathrm{~d}$ & Adults \\
& 5 & $76.7 \mathrm{~b}$ & $82.1 \mathrm{~b}$ & $88.5 \mathrm{a}$ \\
\multirow{2}{*}{ Sulfur } & 7 & $94.8 \mathrm{a}$ & $95.3 \mathrm{a}$ & $82.0 \mathrm{a}$ \\
& 2 & $50.3 \mathrm{c}$ & $47.3 \mathrm{c}$ & $63.7 \mathrm{~b}$ \\
& 5 & $79.5 \mathrm{~b}$ & $48.2 \mathrm{c}$ & $65.9 \mathrm{~b}$ \\
\end{tabular}

Means followed by the same letter in each column are not significantly different at 0.05 level by LSD test. 

From the foregoing results, T. urticae was the major pest on eggplant during autumn and summer seasons. Regarding meteorological parameters, PSD was the main factor effecting on stages of T. urticae. Also, treatments of abamectin and micronized had promise effect on this pest.

\section{REFERENCES}

Abdel-Halim, S.M. (1994). The simultaneous effect of four weather factors on the field infestation of the cotton leafworm Spodoptera littoralis (Boisd.) in six successive years. Egypt. J. Agric. Res., 72(1): 81-89.

El-Halawany, M.E.; R.G. Abou-El-Ela and H.M. Esmail (1990). Population dymanics of mites and their natural enemies on apple and apricot trees. Agric. Res. Rev., 68: 59-66.

Farrag, R.M. and E.A. Zakzouk (1998). Effects of some pesticides on pests and their predators in eggplant fields. Alex. Sci. Exch. 19(3): 507-512.

Giraldo, A.S.; A. Pallini and M. Venzon (2013). Efficacy of lime sulphur in control of mites Tetranychus evansi Baker and Pritchard and Tetranychus urticae Koch (acari: tetranychidae). Revista Luna Azul, 37: 63-73.
Henderson, C.F. and E. Tilton (1955). Tests with acaricides against the brown wheat mite. J. Econ.Entomol. 48: 157161.

Ho, C.C. and W.H. Chen (1992). Species survey of spider mites and seasonal occurrence of Thrips palmi, Chlorita biguttula and Tetranychus cinnabarinus on eggplant. Chinese J. Entomol. 12(4): 259-268.

Nagai, K. (1991). Integrated control of programs for Thrips palmi on eggplant (Solanum melongena L.) in an open field. Japanase J. App. Entomol. \& Zoology 35(4): 283289.

Nour El-Deen, M.E.M. and A.A.M. Abdallah (2013). Effect of different compounds against Tetranychus urticae Koch and its predatory mite Phytoseiulus persimilis A.H. under laboratory conditions. J. App. Sci. Res., 9 (6): 3965-3973.

Steel, R.G. and J.H. Torrie (1980). Principles and procedures of statistics. A. Biometrical approch, $2^{\text {nd }}$ ed. Mc Graw-Hill Book Co., New York.

Zakzouk, E.A. and R.M. Farrag (1998). Effect of climatic conditions on some mite species on orange trees in Alexandria. Alex. Sci. Exch., 19(3): 455-463. 


\section{تأثيرك الالروف المناخية عل توزع وتنبف بهض الآتل عل نبلتل الباننجل خلال العروتن الصيف والخرف}

رمضان محمد فراج، إعسان لحمد زقزوق

كذك أنخفضت تعداد الآفات الأخرى المتولجة مقارن ة

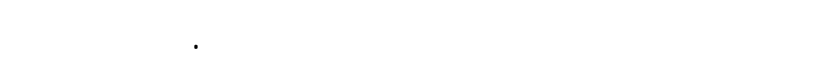


نباتنات الباذنجان الأسود في العروتين.

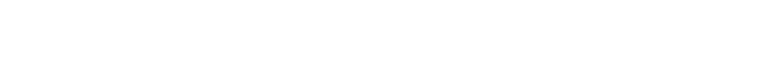

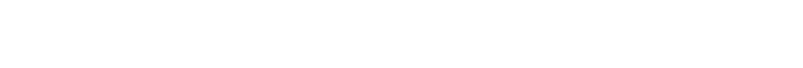

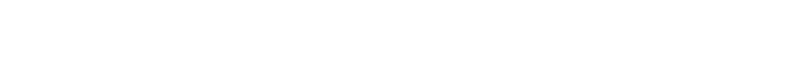
بيض الأكاروس الأحمر يليها درجلت الح _رارة القص -وى لئي

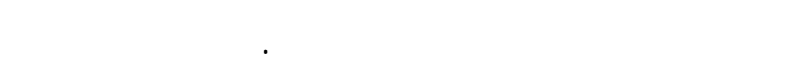



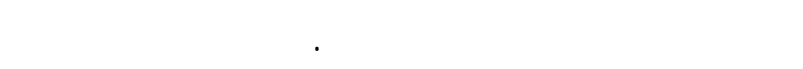


والحيوان الكلمل للألكاروس.

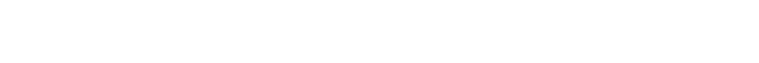

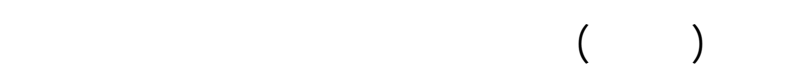



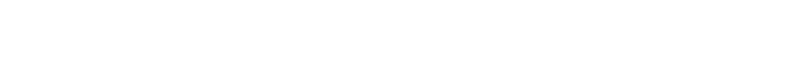
الواضح الفعل للمبيد الحيوى بعد V أيله من المعلملة.
لمستهوف البهث لٕظهار الإختلافلت فى أنواع وتعداد

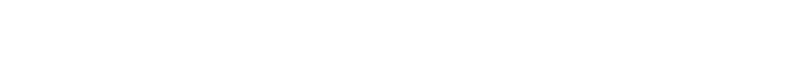


والخريفى فى الإسكندرية. وأظهرت النتائج تولجد الأك اروس الأحم _ر والنباد ـة البيضاء وفرلشة درنات الطلطس والدوة النصف قيلس ـة

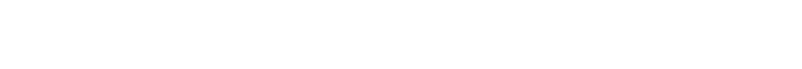

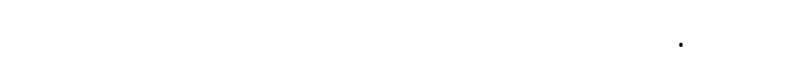





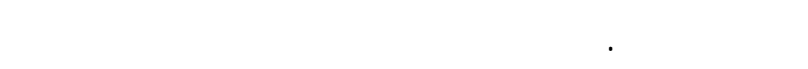

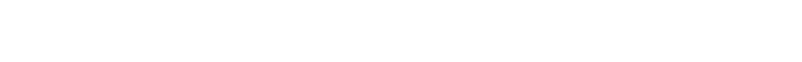



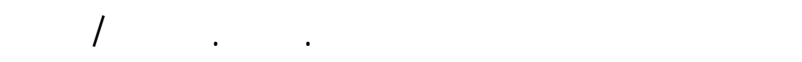

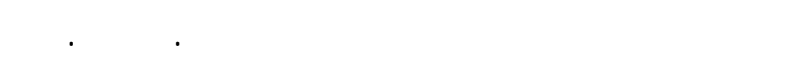
10.1 على التواله فل العروة الصفي. 